\title{
Analisis Pengetahuan dan Alasan Penggunaan Kontrasepsi Suntik di Masyarakat Panyileukan Bandung
}

\section{Analysis of Knowledge and Reasons to Use Contraceptive Injection in the Panyileukan Community Bandung}

\author{
Ani Anggriani*, Deni Iskandar, Devi Aharyanti \\ Fakultas Farmasi, Universitas Bhakti Kencana, Jl. Soekarno Hatta No. 754, \\ Bandung 40614, Jawa Barat, Indonesia \\ *Corresponding author email: ani.anggriani@bku.ac.id
}

Received 10-10-2019 Accepted 30-11-2019 Available online 30-12-2019

\begin{abstract}
ABSTRAK
Metode kontrasepsi yang paling banyak digunakan peserta KB aktif di Indonesia tahun 2014 adalah suntikan (47,54\%). Karena rendahnya pendidikan dan kurangnya pengetahuan masyarakat mengakibatkan banyaknya perempuan mengalami kesulitan dalam menentukan jenis kontrasepsi dan sering menyebabkan wanita beralih ke metode lain bahkan mengakibatkan banyak wanita yang berhenti menggunakan kontrasepsi hingga terjadi kehamilan yang tidak diinginkan. Tujuan penelitian ini adalah untuk mengetahui gambaran pengetahuan dan alasan menggunakan kontrasepsi suntik pada akseptor KB di Panyileukan Bandung. Penelitian ini menggunakan survei deskriptif dengan analisis kuantitatif menggunakan instrumen kuesioner dengan sampel berjumlah 51 responden. Teknik analisis data menggunakan analisis univariat dan bivariat. Sebesar $72 \%$ responden memiliki tingkat pengetahuan cukup baik. Alasan penggunaan kontrasepsi suntik pada akseptor KB secara berturut-turut adalah karena aspek manfaat kontrasepsi suntik 74,83\%, kemudahan menggunakan kontrasepsi suntik (74,50\%), kenyamanan menggunakan kontrasepsi suntik $(72,71 \%)$, dan biaya metode kontrasepsi suntik (67,81\%). Tidak terdapat hubungan antara pengetahuan dengan jenis kontrasepsi suntik dengan p-value 0,310. Hasil penelitian menunjukkan bahwa responden memiliki tingkat pengetahuan cukup baik dan alasan menggunakan kontrasepsi suntik paling banyak adalah karena aspek manfaat kontrasepsi suntik tersebut.
\end{abstract}

Kata kunci: alasan, kontrasepsi suntik, keluarga berencana. 


\begin{abstract}
The most widely used contraceptive method in Indonesia in 2014 was injection (47.54\%). The lack of education, as well as community knowledge, resulted in many women having difficulty in choosing the right contraception type. As a result, switching to other contraception methods and even drop out that lead to an unwanted pregnancy commonly occurred. The purpose of the research was to find out the description of knowledge and reasons to use contraceptive injection on the contraceptive acceptors in Panyileukan, Bandung. The method was a descriptive survey using questionnaires as an instrument involving 51 respondents. Data were analyzed using univariate and bivariate statistical analyses. The result showed that $72 \%$ of respondents have a fairly good level of knowledge. Reasons to use contraceptive injection in contraceptive acceptors were including benefits (74.83\%), practicability (74.50\%), comfort (72.71\%), and cost (67.81\%). There was no correlation between knowledge with the type of contraceptive injection ( $p$ value 0.310).
\end{abstract}

Key words: contraceptive injection, family planning acceptors, reasons.

\section{Pendahuluan}

Dalam

pertumbuhan penduduk, pemerintah mencanangkan program Keluarga Berencana (KB). Menurut Peraturan Pemerintah Republik Indonesia Nomor 87 Tahun 2014 tentang Perkembangan Kependudukan dan Pembangunan Keluarga, KB, dan Sistem Informasi Keluarga, yang dimaksud dengan program KB adalah upaya mengatur kelahiran anak, jarak dan usia ideal melahirkan, mengatur kehamilan, melalui promosi, perlindungan, dan bantuan sesuai dengan hak reproduksi untuk mewujudkan keluarga yang berkualitas (PP, 2014).

Salah satu cara untuk melaksanakan program KB adalah dengan kontrasepsi. Kontrasepsi berasal dari kata kontra yang berarti mencegah atau melawan, sedangkan konsepsi yang berarti pertemuan antara sel telur yang matang dan sel sperma yang mengakibatkan kehamilan (Sarsanto, 2007).

Metode kontrasepsi yang paling banyak digunakan oleh peserta KB aktif di Indonesia adalah suntikan (47,54\%) dan terbanyak kedua adalah pil (23,58\%). Sedangkan metode kontrasepsi yang paling sedikit dipilih oleh peserta KB aktif yaitu Metoda Operasi Pria (MOP) sebanyak 0,69\%, kemudian kondom sebanyak 3,15\%. Sedangkan pada peserta KB baru, persentase metode kontrasepsi yang terbanyak digunakan yaitu suntikan sebesar $49,67 \%$. Metode terbanyak ke dua yaitu pil, sebesar 25,14\%. Metode yang paling sedikit dipilih oleh para peserta KB baru adalah MOP sebanyak $0,21 \%$, kemudian metode operasi wanita (MOW) sebanyak 1,50\%, dan kondom (5,68\%) (BKKBN, 2015).

Dari data-data tersebut, menunjukkan bahwa kontrasepsi suntik menempati peringkat pertama 
dibandingkan kontrasepsi yang lain. Kontrasepsi hormonal jenis KB suntikan ini di Indonesia semakin banyak dipakai karena kerjanya yang efektif, pemakaiannya yang praktis, harganya relatif murah dan aman, bekerja dalam waktu lama, tidak mengganggu menyusui, dan dapat dipakai segera setelah keguguran atau setelah masa nifas. Serta pemilihan bidan praktek sebagai tempat pelayanan KB banyak dipilih oleh masyarakat atau akseptor KB. Rendahnya pendidikan dan kurangnya pengetahuan masyarakat mengakibatkan banyaknya perempuan mengalami kesulitan dalam menentukan jenis kontrasepsi dan sering menyebabkan wanita beralih ke metode lain bahkan mengakibatkan banyak wanita yang berhenti menggunakan kontrasepsi hingga terjadi kehamilan yang tidak diinginkan. Tujuan penelitian ini adalah untuk mengetahui karakteristik akseptor KB pengguna kontrasepsi suntik, tingkat pengetahuan akseptor KB tentang kontrasepsi suntik, dan alasan penggunaan kontrasepsi suntik berdasarkan aspek manfaat, kenyamanan, kemudahan metode kontrasepsi suntik di Masyarakat Panyileukan Bandung.

\section{Metode Penelitian}

Penelitian ini merupakan penelitian survei deskriptif dengan pengambilan data menggunakan kuesioner yang telah diuji validitas dan reliabilitas (Gambar 1). Sampel penelitian berjumlah 51 responden yang merupakan akseptor kontrasepsi suntik di masyarakat Panyileukan RW 09 dan RW 10 dengan teknik analisis data menggunakan analisis univariate yaitu variabel dari karakteristik responden meliputi usia, pendidikan, pekerjaan, pendapatan, jumlah anak kandung, jumlah anak yang diinginkan, sumber informasi, dan jenis KB suntik. Untuk analisis bivariate dengan menggunakan uji chi-square dengan tingkat kepercayaan $95 \%(p<0,05)$ antara tingkat pengetahuan responden terhadap jenis kontrasepsi suntik yang digunakan.

\section{Hasil dan Pembahasan}

Karakteristik dari 51 responden terdiri dari usia, pendidikan, pekerjaan, penghasilan, jumlah anak kandung, jumlah anak yang diinginkan, dan sumber informasi responden. Karakteristik responden disajikan dalam Tabel 1.

Pada umumnya usia akan mempengaruhi seseorang dalam menentukan pemilihan alat kontrasepsi karena biasanya ibu dengan usia muda (baru pertama kali menggunakan alat kontrasepsi) akan cenderung memilih kontrasepsi yang kebanyakan orang pakai. Pada usia antara 15 hingga 49 tahun merupakan usia dimana seseorang masih dalam tahap masa subur dan masih dapat bereproduksi. Pada usia kurang dari 20 tahun merupakan masa menunda kehamilan, usia 20-35 tahun menjarangkan kehamilan dan pada usia di atas 35 tahun merupakan masa dimana wanita untuk mencegah kehamilan. 


\section{Scale: ALL VARIABLES}

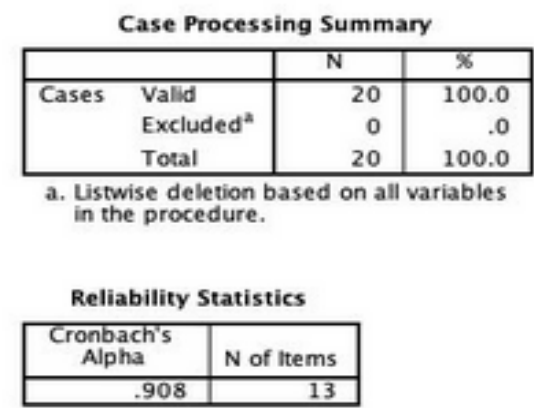

\begin{tabular}{|l|l|r|r|}
\hline \multicolumn{4}{|c|}{ Item Statistics } \\
\hline & Mean & $\begin{array}{c}\text { Std. } \\
\text { Deviation }\end{array}$ & $\mathrm{N}$ \\
\hline butir_1 & 2.7500 & .85070 & 20 \\
butir_2 & 2.8000 & .69585 & 20 \\
butir_3 & 3.0000 & .72548 & 20 \\
butir4 & 3.1500 & .74516 & 20 \\
butir5 & 3.2000 & .76777 & 20 \\
butir6 & 3.0000 & .79472 & 20 \\
butir7 & 3.2500 & .78640 & 20 \\
butir8 & 3.2000 & .52315 & 20 \\
butir9 & 2.7000 & .65695 & 20 \\
butir10 & 2.9000 & .91191 & 20 \\
butir11 & 3.0500 & .75915 & 20 \\
butir12 & 2.9000 & .64072 & 20 \\
butir13 & 2.9500 & .68633 & 20 \\
\hline
\end{tabular}

Gambar 1. Uji validitas dan realibilitas kuisioner.

\begin{abstract}
Pada umumnya usia akan mempengaruhi seseorang dalam menentukan pemilihan alat kontrasepsi karena biasanya ibu dengan usia muda (baru pertama kali menggunakan alat kontrasepsi) akan cenderung memilih kontrasepsi yang kebanyakan orang pakai. Pada usia antara 15 hingga 49 tahun merupakan usia dimana seseorang masih dalam tahap masa subur dan masih dapat bereproduksi. Pada usia kurang dari 20 tahun merupakan masa menunda kehamilan, usia 20-35 tahun menjarangkan kehamilan dan pada usia di atas 35 tahun merupakan masa
\end{abstract}

dimana wanita untuk mencegah kehamilan.

Tingkat pendidikan seseorang akan memberikan pengaruh yang menyangkut respon yang berasal dari luar. Orang yang berpendidikan tinggi akan lebih luas pandangannya dan lebih mudah menerima ide atau tata cara kehidupan baru termasuk salah satunya adalah tentang keikutsertaan menggunakan kontrasepsi KB. Orang yang berpendidikan tinggi juga lebih dapat menyesuaikan diri terhadap perubahan-perubahan sosial. Sebaliknya, tingkat pendidikan yang rendah akan menghambat perkembangan sikap 
seseorang terhadap nilai-nilai baru yang diperkenalkan (Fienalia, 2012). Pernyataan tersebut sesuai dengan hasil penelitian dimana berdasarkan hasil penelitian persentase yang paling tinggi adalah wanita dengan pendidikan tamat SMA.

Tabel 1. Karakteristik responden

\begin{tabular}{|c|c|c|c|c|}
\hline No & Variabel & Defini Operasional & Frequensi & $\begin{array}{c}\text { Persentase } \\
\text { (\%) }\end{array}$ \\
\hline \multirow[t]{5}{*}{1} & Usia & $<20$ & 4 & 8 \\
\hline & (tahun) & $20-25$ & 16 & 31 \\
\hline & & $26-30$ & 14 & 27 \\
\hline & & $31-35$ & 8 & 16 \\
\hline & & $>35$ & 9 & 18 \\
\hline \multirow[t]{4}{*}{2} & Pendidikan & Tamat SD & 0 & 0 \\
\hline & & Tamat SMP & 0 & 0 \\
\hline & & Tamat SMU & 47 & 92 \\
\hline & & Perguruan Tinggi & 4 & 8 \\
\hline \multirow[t]{3}{*}{3} & Pekerjaan & IRT & 47 & 92 \\
\hline & & Wiraswasta & 2 & 4 \\
\hline & & Karyawan & 2 & 4 \\
\hline \multirow[t]{3}{*}{4} & Pendapatan & $<1$ & 0 & 0 \\
\hline & (juta) & $1-5$ & 44 & 86 \\
\hline & & $>5$ & 7 & 4 \\
\hline \multirow[t]{5}{*}{5} & Jumlah & 1 anak & 25 & 49 \\
\hline & anak & 2 anak & 12 & 24 \\
\hline & kandung & 3 anak & 10 & 20 \\
\hline & & 4 anak & 1 & 2 \\
\hline & & $>4$ anak & 3 & 6 \\
\hline \multirow[t]{5}{*}{6} & Jumlah & 1 anak & 2 & 4 \\
\hline & anak yang & 2 anak & 26 & 51 \\
\hline & diinginkan & 3 anak & 18 & 35 \\
\hline & & 4 anak & 2 & 4 \\
\hline & & $>4$ anak & 3 & 6 \\
\hline \multirow[t]{3}{*}{7} & Sumber & Anjuran Petugas Kesehatan & 20 & 40 \\
\hline & Informasi & Teman, Saudara atau Keluarga & 15 & 29 \\
\hline & & Media Cetak, Elektronik, Media social & 16 & 31 \\
\hline \multirow[t]{2}{*}{8} & Jenis KB & Suntik 1 bulan & 9 & 18 \\
\hline & Suntik & Suntik 3 bulan & 42 & 82 \\
\hline
\end{tabular}

Wanita yang bekerja memiliki nilai waktu yang mahal sehingga kesempatan untuk mengurus anak lebih sedikit dibandingkan dengan wanita yang tidak bekerja, sehingga wanita yang bekerja akan cenderung membatasi jumlah anak. Selain itu, wanita yang berpendidikan relatif tinggi dan bekerja 
akan cenderung berpikiran rasional bahwa dengan ukuran keluarga yang kecil akan menjadi suatu keluarga yang lebih baik dan dengan masa depan yang lebih terjamin. Penggunaan kontrasepsi suntik pada wanita yang bekerja hal ini didasari karena kontrasepsi suntik memiliki efektivitas yang lebih baik dan mereka akan terhindar dari faktor lupa dibandingkan dengan menggunakan kontrasepsi jenis pil.

\section{Penghasilan}

seseorang

meningkat maka kemampuan untuk membeli berbagai kebutuhan rumah tangga akan semakin besar dan mungkin juga gaya hidup akan berubah menjadi lebih konsumtif. Setidaknya akan menuntut kualitas hidup yang lebih baik. Begitupun dengan memilih metode kontrasepsi yang akan digunakan karena penghasilan yang cukup akan menuntut seseorang untuk memilih alat kontrasepsi yang lebih baik pula. Menurut Bertrand dalam Fienalia (2012) menyatakan bahwa salah satu faktor yang mempengaruhi penggunaan kontrasepsi adalah status sosial ekonomi. Semakin tinggi status ekonomi seseorang, maka semakin mudah untuk menggunakan kontrasepsi. Hal tersebut diperkuat dengan hasil penelitian yang telah dilakukan oleh Wulandari dan Hastuti (2013), menyatakan bahwa terdapat hubungan yang sangat signifikan antara pendapatan akseptor KB dengan pemilihan kontrasepsi suntik.

Selain dikarenakan efektifitas yang lebih baik, harga kontrasepsi suntik lebih terjangkau jika dibandingkan dengan metode IUD atau metode kontrasepsi lain. Meskipun harga kontrasepsi suntik sedikit lebih mahal dibandingkan dengan harga kontrasepsi pil tetapi untuk penggunaanya lebih praktis dan dapat terhindar dari faktor lupa ketika saat harus menggunakan pil KB.

Data SDKI tahun 2012 menyatakan bahwa penggunaan kontrasepsi meningkat menurut jumlah anak masih hidup yang dimiliki. Penggunaan metode kontrasepsi berkisar antara $7 \%$ di antara wanita yang belum memiliki anak sampai $70 \%$ di kalangan wanita dengan tiga atau empat anak yang masih hidup, kemudian turun menjadi 52\% untuk wanita dengan lima anak atau lebih. Metode kontrasepsi yang paling popular di antara wanita yang belum memiliki anak adalah suntikan KB dan pil (masing-masing $3 \%$ ). Penggunaan suntikan KB meningkat secara substansial setelah memiliki anak pertama, puncaknya adalah 38\% pada wanita dengan satu atau dua anak. Sedangkan proporsi wanita yang menggunakan sterilisasi dari $1 \%$ untuk wanita dengan satu atau dua anak menjadi $8 \%$ untuk wanita dengan tiga atau empat anak. Hal ini menunjukkan bahwa wanita yang menggunakan kontrasepsi suntik yang memiliki 1 anak sedang dalam masa perencanaan jumlah anak. Sedangkan wanita yang memiliki anak lebih dari 2 bahkan lebih dari 4 anak akan cenderung memilih kontrasepsi mantap atau sterilisasi yang lebih efektif dan jangka panjang dibandingkan dengan kontrasepsi jenis suntikan. Jumlah anak yang diinginkan 
(demand for children) merupakan salah satu faktor penting dalam pengambilan keputusan penggunaan alat kontrasepsi $\mathrm{KB}$.

Petugas kesehatan berperan dalam pemberian informasi, penyuluhan dan menjelaskan tentang alat kontrasepsi terutama kontrasepsi hormonal. Petugas kesehatan sangat banyak berperan dalam tahap akhir pemakaian alat kontrasepsi. Dimana calon akseptor yang masih ragu-ragu dalam pemakaian alat kontrasepsi akhirnya memutuskan untuk memakai alat kontrasepsi setelah mendapat dorongan maupun anjuran dari petugas kesehatan. Petugas kesehatan merupakan faktor yang berperan dalam tahap akhir pemakaian kontrasepsi pada akseptor. Pada saat ini radio dan televisi banyak menampilkan drama dan diskusi mengenai keluarga berencana, hal tersebut juga merupakan salah satu sumber informasi. Selain itu dengan semakin majunya era sekarang lebih memudahkan seseorang untuk mengakses berbagai hal melalui internet termasuk mengenai kontrasepsi dan keluarga berencana. Wanita dengan pendidikan yang lebih tinggi lebih mudah menerima informasi mengenai keluarga berencana dari berbagai sumber dibandingkan dengan wanita yang berpendidikan rendah. Tetapi anjuran petugas kesehatan pada akhirnya tetap menjadi salah satu pertimbangan dalam memilih kontrasepsi yang digunakan (Farahan, 2014).

Seorang akseptor yang menggunakan kontrasepsi suntik 3 bulan hanya perlu datang setiap tiga bulan sekali untuk melakukan penyuntikan berulang. Dibandingkan dengan suntikan 1 bulan, suntikan 3 bulan lebih jangka panjang. Bagi aksetor dengan penghasilan rendah hanya perlu mengeluarkan biaya setiap 3 bulan sekali pada waktu akan melakukan penyuntikan. Selain itu seorang wanita yang memiliki aktivitas tinggi, akan merasa lebih nyaman dan leluasa jika menggunakan suntik 3 bulan karena tidak harus kembali setiap bulan untuk penyuntikan, tetapi masih banyak faktor lain yang mempengaruhi seseorang dalam memilih dan menggunakan suatu kontrasepsi.

Tingkat Pengetahuan

Pengukuran

tingkat

pengetahuan dilakukan dengan menggunakan kuisioner dengan pertanyaan mengenai kontrasepsi suntik. Menurut Arikunto (2013) pengukuran tingkat pengetahuan dibagi menjadi 3 macam kategori (Tabel 2).

Berdasarkan hasil analisis yang telah dilakukan kepada 51 responden terhadap 8 pertanyaan mengenai pengetahuan, didapatkan hasil rata-rata sebesar $72 \%$ yang menunjukkan bahwa pengetahuan responden tersebut cukup baik (Gambar 2). 
Tabel 2. Kategori pengukuran tingkat pengetahuan

\begin{tabular}{ccc}
\hline No. & Kategori Tingkat Pengetahuan & Nilai \\
\hline 1. & Kategori baik & $>75 \%$ \\
2. & Kategori cukup & $60-75 \%$ \\
3. & Kategori kurang & $<60 \%$ \\
\hline
\end{tabular}

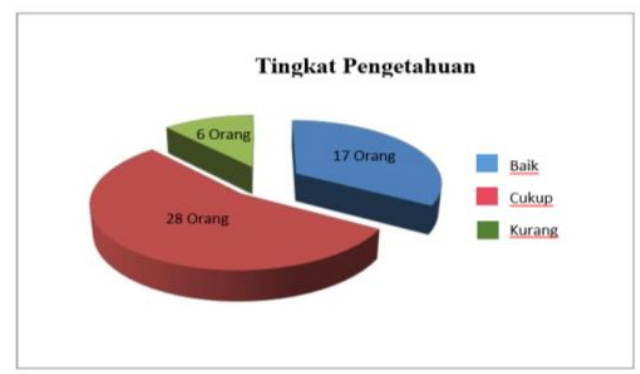

Gambar 2. Tingkat pengetahuan responden.

Hasil penelitian sebelumnya yang telah dilakukan oleh Nindyakaryawati et al. (2018), menyatakan bahwa ada hubungan antara pengetahuan dengan pemilihan alat kontrasepsi suntik secara rasional. Salah satu faktor yang mempengaruhi tingkat pengetahuan seseorang apabila pengetahuan tinggi maka responden lebih memilih alat kontrasepsi suntik karena lebih tahu alat kontrasepsi yang efektif.

\section{Alasan Penggunaan Kontrasepsi Suntik} Berdasarkan pemaparan dan analisis data yang telah dipaparkan pada Tabel 3, dapat diketahui bahwa alasan yang paling banyak adalah pada aspek manfaat dimana kontrasepsi suntik merupakan alat kontrasepsi yang dapat digunakan setelah melahirkan, kontrasepsi suntik tidak mempengaruhi kualitas dan volume ASI, dan merupakan metode jangka panjang dibandingkan pil
KB. Alasan yang kedua adalah kemudahan menggunakan kontrasepsi suntik dalam hal ini responden tidak kesulitan untuk melakukan penyuntikan karena adanya sarana kesehatan yang baik. Alasan yang ketiga adalah kenyamanan menggunakan kontrasepsi suntik dan alasan yang keempat adalah biaya metode kontrasepsi suntik dalam hal ini responden harus menyediakan biaya yang sedikit lebih tinggi dibandingkan dengan kontrasepsi pil, dan adanya biaya tambahan ke tempat pelayanan KB/bidan setiap kali penyuntikan.

Setelah diketahui alasan
penggunaan kontrasepsi
suntik,
atau tidak keempat aspek tersebut
dalam hal memilih dan menggunakan
kontrasepsi suntik. Hasil pengolahan
data disajikan pada Gambar 3.
data disajikan pada Gambar 3. 
Tabel 3. Alasan penggunaan kontrasepsi suntik

\begin{tabular}{lc}
\hline Aspek alasan & $\%$ \\
\hline Manfaat & 74,83 \\
Kenyamanan & 72,71 \\
Kemudahan & 74,50 \\
Biaya & 67,81 \\
\hline
\end{tabular}

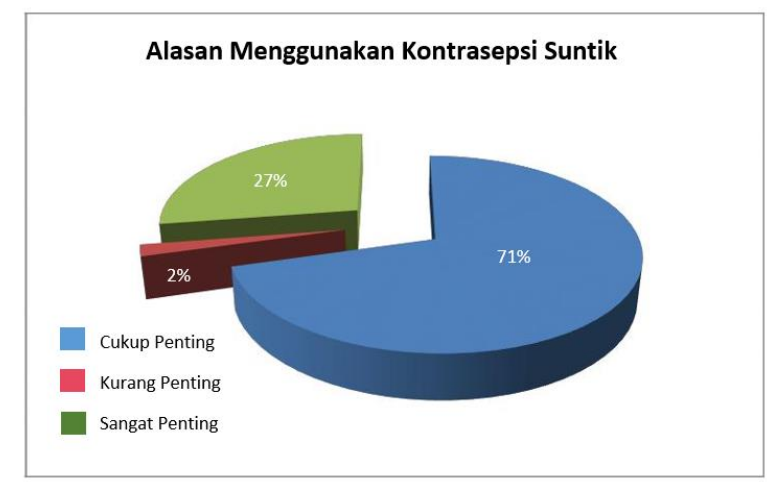

Gambar 3. Alasan penggunaan kontrasepsi suntik.

Dari 51 responden, sebanyak 71\% menyatakan bahwa keempat aspek alasan tersebut cukup penting. Alasan tersebut dapat menjadi pertimbangan dalam hal memilih dan menggunakan kontrasepsi jenis suntik.

Hubungan Antara Pengetahuan dengan Jenis Kontrasepsi Suntik yang Sedang Digunakan

Hasil analisis hubungan antara pengetahuan dengan jenis kontrasepsi suntik yang sedang digunakan dapat dilihat pada Tabel 4. Berdasarkan hasil analisis chi square antara jenis kontrasepsi suntik yang digunakan dengan pengetahuan didapatkan nilai $p>0,05$ sebesar 0,310 . Dilihat dari nilai tersebut maka dapat dinyatakan tidak terdapat hubungan antara pengetahuan dengan jenis kontrasepsi suntik yang digunakan. Hal ini menunjukkan bahwa pengetahuan tentang kontrasepsi suntik tidak mempengaruhi dalam pemilihan kontrasepsi suntik. Pengaruh alasan penggunaan dari kemanfaatan, kenyamanan, kemudahan, dan biaya menjadi parameter untuk memilih jenis kontrasepsi suntik yang sesuai dengan keinginan responden.

Hasil tersebut tidak sesuai dengan hasil penelitian sebelumnya yang pernah dilakukan oleh Nindyakaryawati et al. (2018), menyatakan bahwa ada hubungan antara pengetahuan, dengan pemilihan alat kontrasepsi suntik secara rasional. 
Tabel 4. Tabulasi silang dan chi square pengetahuan dengan jenis suntik KB yang digunakan

\begin{tabular}{|c|c|c|c|c|c|}
\hline \multirow{3}{*}{ Pengetahuan } & \multicolumn{4}{|c|}{ Jenis KB Suntik yang Digunakan } & \multirow{3}{*}{ Significancy } \\
\hline & \multicolumn{2}{|c|}{1 Bulan } & \multicolumn{2}{|c|}{3 Bulan } & \\
\hline & $F$ & $\%$ & $F$ & $\%$ & \\
\hline Baik & 4 & 7,8 & 15 & 29,4 & \multirow{4}{*}{0,310} \\
\hline Cukup & 5 & 9,8 & 18 & 35,3 & \\
\hline Kurang & - & 0,0 & 9 & 17.6 & \\
\hline Jumlah & 9 & 17,6 & 42 & 82,4 & \\
\hline
\end{tabular}

\section{Simpulan}

Tingkat pengetahuan responden tentang kontrasepsi suntik termasuk ke dalam kategori cukup baik. Alasan menggunakan kontrasepsi suntik yang paling banyak adalah manfaat kontrasepsi suntik, kemudian kemudahan menggunakan kontrasepsi suntik, kenyamanan menggunakan kontrasepsi suntik, dan biaya kontrasepsi suntik. Sebanyak $71 \%$ responden dari 51 responden pengguna kontrasepsi suntik menyatakan bahwa keempat aspek alasan yaitu manfaat, kenyamanan, kemudahan serta pembiayaan kontrasepsi suntik merupakan hal yang penting dan menjadi pertimbangan dalam memilih dan menggunakan kontrasepsi suntik. Tidak terdapat hubungan antara pengetahuan dengan jenis kontrasepsi suntik yang digunakan.

\section{Daftar Pustaka}

Arikunto, S. 2013. Prosedur Penelitian: Suatu Pendekatan Praktik. Jakarta: Rineka Cipta.

BKKBN. 2015. Profil Kependudukan dan Pembangunan di Indonesia. Jakarta: BKKBN.
Farahan, N. 2014. Gambaran tingkat pengetahuan penggunaan alat kontrasepsi pada wanita usia subur dan dukungan petugas di Desa Bebandem Kabupaten Karangasem Bali. E-Jurnal Medika Udayana, 5(4):112.Peraturan Pemerintah Nomor 87 Tahun 2014 Tentang Perkembangan Kependudukan dan Pembangunan Keluarga Berencana dan Sistem Informasi Keluarga.

Fienalia, R.A. 2012. Faktor-faktor yang berhubungan dengan pemilihan metode kontrasepsi jangka panjang (MKJP) di wilayah kerja Puskesmas Pancoran Mas Kota Depok Tahun 2011. Skripsi. Program Studi Kesehatan Reproduksi, Fakultas Kesehatan Masyarakat. SDKI. 2012. Survei Demografi Kesehatan Indonesia. Jakarta: BKKBN.

Nindyakaryawati, T.S., Sakung, J., Hamidah. 2018. Hubungan pengetahuan dan tingkat pendapatan dengan pemilihan non metode kontrasepsi jangka panjang (N-MKJP) di Kelurahan Tanamodindi Wilayah Kerja Puskesmas Kawatuna. Jurnal 
Kesehatan Masyarakat Unismuh Palu, 1(1):656-664.

Sarsanto. 2007. Pelayanan Keluarga Berencana (KB). Jakarta: EGC.
Wulandari, I.F. dan Hastuti, R. 2013. Hubungan tingkat pendapatan keluarga dengan pemilihan alat kontrasepsi suntik. Jurnal Infokes Universitas Duta Bangsa Surakarta, 3(3):14-24. 